\title{
FORUM
}

\section{CONTOURS OF AN ISRAELI-PALESTINIAN PEACE SETTLEMENT}

\author{
ANTHONY OBERSCHALL ${ }^{1}$
}

\begin{abstract}
Israelis and Palestinians have off-loaded the cost of their conflict to outsiders. The massive subsidies for Palestinians should be gradually withdrawn and Israel should pay rent for the settlements and lands it occupies. This rent will fund the Palestinian economy and act as compensation in lieu of the right of return. The Palestinian state will be demilitarized and neutral, and become viable through economic ties to Israel and international aid. Two states will coexist along the 1967 Green Line, and East Jerusalem will be made part of "Jerusalem: one city, two capitals." Peace-making will be backed by the major international stakeholders and the agreement will be legitimized by voters in both countries.

No one is under any illusions about the obstacles to an Israeli-Palestinian peace agreement. Yet ideas that seem far fetched in time become actionable: for decades no one expected that majority rule in South Africa would be peacefully achieved, and few anticipated that Franco-German cooperation and alliance after two bloody World Wars would give birth to the European Union.
\end{abstract}

KEYWORDS: peace settlement, Israel, Palestine, refugees, aid, failed state

\section{OBSTACLES TO PEACE}

Both adversaries profoundly mistrust one another and are internally divided about a "two-state solution." Israelis believe that an independent Palestinian state will be a weak or failed state, not able to prevent attacks on Israel, as has been the Gaza experience, and that security will require Israeli re-invasion of the presently Occupied Territories (OT) and military operations, as in Gaza. A peace process might precipitate civil strife among Palestinians, as happened

\footnotetext{
1 Anthony Oberschall is professor emeritus at the Univ. of N. Carolina, Chapel Hill; e-mail: tonob@email.unc.edu
} 
in Gaza when Hamas ousted Fatah through violence, and result in a hostile, unstable state controlled by religious and nationalist extremists. The status quo is preferable for many Israelis.

Palestinians believe that an Israeli government will not be able or willing to deliver East Jerusalem as their capital or evacuate many West Bank (WB) settlements, outposts, and illegal Israeli sites because armed settlers and their allies will resist the Israel Defense Forces (IDF), and Israelis will refuse to shoot one another. A Palestine state will thus remain a "Swiss cheese" entity with limited sovereignty, and, like the status quo, not a viable independent state. Palestinian leaders also fear that signing the agreement might trigger civil war among Palestinians and their assassination by militants. The status quo is preferable for many Palestinians.

Neither adversary has had to pay the cost of the conflict. For decades Israelis and Palestinians have outsourced the costs of occupation to the international community and to their allies, who have become enablers of the status quo. Paying the costs of the conflict for the Palestinians means phasing out billions in international subsidies; for the Israelis it means bearing the full cost of the military occupation of the Israeli Occupied Territories under international law, including compensating the Palestinians for the Israeli-occupied West Bank land.

Any peace agreement has to achieve a better and realistic future for both adversaries compared to the status quo: Israel has to have security, and a Palestinian state has to have a viable economy. Israel has an interest in having a viable Palestinian as a neighbor instead of a failed state vulnerable to extremists. Two states and two peoples can coexist and prosper throughout the entire Israel/ Palestine area in what is potentially an economic "common market," but such cooperation keeps being disrupted by violent conflict and threats to normal life. According to the historian Ilan Pappe, "Palestinians were sucked into the pool of labor needed by the Israeli economy...they provided nearly a quarter of the labor in Israeli industry in the mid 1970s [A History of Modern Palestine, p.202]. In the 1980s, before the first intifada, about one-third of the Palestinian work force was employed in Israel. Nowadays, 80,000 work permits have been issued for Palestinians to work in Israel, and thousands more Palestinians work illegally in Israeli settlements. One hundred and twenty thousand Palestinian workers commute to Israel every day [NYT 1/5/18]. The Palestinian Prime Minister and the Israeli Finance Minister have recently announced plans to develop three joint industrial free-trade zones in the West Bank [Jerusalem Post 2/22/18]. Economic incentives persist for overcoming political barriers. What is now micro-economic cooperation can develop into macro-economic cooperation when peace gets institutionalized. 
The peace process will gradually deliver security for Israel and build a viable Palestinian state. In the short run, both Israelis and Palestinians will have to make sacrifices. The Palestinians and Israelis by themselves will not work out a successful peace deal. Major outside powers, international agencies and stakeholders must help achieve peace in Palestine, provide resources for the peace transition, refrain from proxy wars by taking sides, and exert pressure against extremists from both sides that are unwilling to compromise.

\section{CONTOURS OF THE PEACE AGREEMENT}

The peace process will take place under the sponsorship and with the assistance of stakeholder states, diplomats, international agencies, and groups of experts (military, jurists, scientists, etc.) The Israeli and Palestinian publics need to know what the contours of the outcome will look like and have assurances about the openness, fairness, and enforcement of the process. During the Oslo process, incremental tinkering with boundaries, settlements, and security arrangements did not build confidence and led to breakdown. A shared vision of realistic peaceful coexistence and recognition of realities has to overturn the collective myths maintained by the Israelis, the Palestinians, and international stakeholders. Reality 1: Israel is permanent and will remain a Jewish state; the Palestinians are permanent and will not be a quasi-colony of Israel or pushed out into other Arab states. Reality 2: Israel is an occupying power in WB and East Jerusalem. It has to assume the responsibilities of military occupation. Reality 3: Palestinians have the unparalleled status of having the oldest unsettled refugee population in UN history and are the largest per-capita recipients of foreign assistance worldwide. The Palestinian state must end such dependency, develop a viable economy, and assume the responsibilities of a normal state. Reality 4 . The end of the peace process will involve a peace agreement by two sovereign states, Israel and the Palestinian state, endorsed by the international community and legitimized by the majority of voters of both states.

Two states, Israel and a Palestinian state, will be defined along the Green Line boundary (the 1967 armistice line); East Jerusalem will be the capital of the Palestinian state but institutions for Jerusalem will be created to make it "One City, Two Capitals" thereby avoiding an East Berlin/West Berlin-type divided city; the Palestinian state will be neutral and demilitarized (like Switzerland) with joint security arrangements with Israel; Israel will financially compensate the Palestinian state for land it occupies on Palestinian territory and does not vacate; in lieu of a failed state, the new Palestinian state will develop viable institutions, and economic cooperation with Israel will benefit both peoples. 


\section{CONCRETE STEPS FOR PEACE}

The adversaries must pay the cost of the conflict. Under the Geneva Conventions, Israel is an occupying power and "the occupying power does not acquire ownership of immovable public property in occupied territory" and the "transfer of civilian populations by the occupying power into occupied territory" is illegal. Israel has not paid for the settling of Israelis on WB land. Under the Geneva Conventions, an occupying power after the end of hostilities must ensure the provision of food, medical care, public health, and education to occupied people. When Jewish settlers arrived in Palestine, they purchased land: "By the end of the 1930's, 40\% of all expenditures of the Jewish Agency was on purchase of land and agricultural colonization" (Pappe, op.cit. pp.94-95); they did not appropriate land without compensation. That changed after 1967. As an expert wrote, “...probably most jurists throughout the world, including many in Israel, regard all the settlements in the West Bank as illegal under international law, specifically article 49 of the Fourth Geneva Convention..." (David Schulman, NYRB, 5/22/14).

Israel has outsourced the obligations of an occupying power to the American government, which provides financial, military, and diplomatic support to Israel, and to American Jewish NGOs and donors. The security cost of maintaining the status quo is huge for Israel. For instance, Israel is building a 40-mile concrete and electronic security barrier costing $\$ 1$ billion deep in the earth at the Gaza border to block tunneling by Hamas and Islamic Jihad (NYT, 2/12/18).

The Palestinians have become the largest per capita recipients of aid (World Bank 2013, European Commission 2017): WBGS received \$495 per capita yearly, double the amount of that received by the next largest group of refugee recipients; in Gaza, 80\% rely on humanitarian aid, mostly for food; UNRWA operates one of largest Middle-Eastern school systems for Palestinians involving half a million students, pays $70 \%$ of the cost of teaching staff, reaching $\$ 750$ per annum per student. The Palestinian refugee status and aid programs created by the UN in 1948 and 1967 have morphed into permanent dependency and an aid economy that dwarfs the real Palestinian economy. The international community and outsiders have become the principal enablers of the status quo. The U.S. pays about $\$ 650$ million a year for all forms of assistance (Congressional Research Service, 12/16/16, "U.S. Foreign aid to Palestinians").

The Palestinian Authority is not held to the norms of a modern state that is responsible for employment, social, health and education services. It will not be a normal state until it has a viable economy. "Refugee" status has enabled the outsourcing of these responsibilities to the international community, especially in Gaza. A stopgap measure has become permanent and has not brought peace and good governance for the Palestinians. 
Outsourcing is coming to an end because the international community, including the U.S., is wary of being an enabler and because refugees and war migrants from Syrian and other catastrophic wars are making huge demands on international assistance (Alex Joffe and Asaf Romirowsky, "The UN agency that keeps Palestinians from prospering" WSJ, 1/10/18). Because thousands of Palestinians' food needs, jobs, and salaries depend on international assistance, this has to be terminated gradually in parallel with the creation of a viable Palestinian economy. International financial and technical assistance (e.g. from the World Bank, EU and Arab states), will be necessary for a considerable time.

Israel will not empty the major settlements in the WB but it will assume the responsibilities of an occupying power and pay rent for settlements and the water they consume because it has an interest in having a viable rather than a failed state for a neighbor. There are about six hundred thousand settlers in blocs adjacent to the 1967 borders, East Jerusalem, and in some 130 settlements scattered throughout the WB. The Palestinian State can lease land currently occupied by these Israeli settlers to Israel; this would involve long-term, 50year leases for settlements and allow for the continuation of Israeli law and authority within them. Leases will also be granted for outposts, military bases, access roads, security barriers, and buffers, and are expected to be phased out after some time. Some settlers will return to Israel voluntarily when the IDF gradually withdraws from the Palestinian state, but some will not. Nevertheless, over time, the "Swiss cheese" aspect of the WB will diminish, without the use of force.

Leasing land would be a cost-effective deal for remaining Israeli settlers in the new Palestinian state and a much needed source of revenue for the Palestinian Authority as international assistance is phased out. There is a precedent: Israel has rented land from Jordan for decades on behalf of the Israeli agricultural/military settlements in the Jordan valley. The assumption of gradual sovereignty by the Palestinian state requires the cessation of settlement expansion and continued loss of Palestinian living space. Concrete benefits accruing to Palestinians from an independent state would include secure property-, residence-, water-, and building rights.

The rents will go to several Palestinian Funds to compensate Palestinian refugees who give up their right of return, for government expenditures to cover the phasing out of international donor aid, and for Palestine state-building and economic development.

A controversial principle is compensation for the right of return, when physical return is not possible, as it is not in any realistic peace settlement. At the termination of many conflicts, like insurgency in South Africa and the Bosnian civil war, and major regime changes at the end of communism in Eastern Europe, 
provisions were made for compensating victims and their families. In South Africa it was part of the Truth and Reconciliation Commission (TRC); in Bosnia it was part of the Dayton peace agreement; in Eastern Europe, in different ways, new democratic regimes restored some property or instituted some compensation schemes. For making a peace settlement acceptable to the Palestinians, there has to be a compensation scheme in lieu of the right of return. Limits have to be put on who is eligible, and what the amounts are; there are precedents from the TRC and from the implementation of Dayton concerning commissions and procedures for doing this. Polls have shown for years that most Palestinians are willing to give up their right of return for financial compensation.

The funds will be managed under international supervision or controls to ensure they are not diverted to other uses; this process is similar to the control exercised by international agencies and donor states for funds allocated to the Palestinian Authority, Palestinian NGOs, and International NGOs for the Palestinians.

A Rand study estimated that a Palestinian state will need a capital investment of $\$ 33$ bn. for the first ten years. The Palestinian Funds will also raise money from other sources like the World Bank, Arab states, and Islamic foundations, the European Union, U.S., and UN agencies. The Funds will pay Israel for electricity, telecommunications, water, port facilities, transportation, technical, and other services provided to the Palestinians (e.g. the technology for irrigation agriculture and water recycling in arid regions that Israel has successfully developed). It is hoped that the economic, labor and financial ties between the two states will gradually grow into permanent cooperative economic institutions, building on labor migration and investments that already exist, perhaps later including other states like Jordan.

East Jerusalem will become the capital of the Palestinian state under "One City, Two Capitals" institutions. The specifics of Jerusalem governance, its boundaries, its economy and governance under the two-state peace agreement will have to be worked out. Palestinian sovereignty will ensure that Palestinians will not lose their right to live in the city and will have voting rights to elect representatives who are accountable for taxes and municipal services. The topic requires a separate analysis and essay. Jerusalem functions now as a unified city, and the outcome to be avoided is a divided West Berlin/East Berlin-type city. Several Israelis and Palestinians have been reflecting on such a plan, cf. Daniel Seidmann “Terrestrial Jerusalem” (YouTube 2/6/18 Jerusalem: City in Crisis). In addition, there would be an international agreement for access to and administration of Temple Mount and other Holy Places. The current arrangements work pretty well and might be continued, but the faith communities will have to be consulted and approve. 
There will be security arrangements and enforcement, including demilitarization of the Palestinian state, banning offensive weapons, internationally recognized neutrality status (precedents Switzerland and Sweden), the decommissioning of weapons held by Hamas and other militant groups under international inspection, the dignified return of fighters to civilian status (as in South Africa, Northern Ireland, and Colombia), the release of prisoners held by Israel, and a declaration by both sides of the cessation of hostilities pending a permanent peace agreement. Fighters would enlist in a "trading violence for jobs or education" program. There will be agreement by all stakeholders to keep offensive military weapons out of the Palestinian state, to secure borders against weapons smuggling, and the commitment of outside states and organizations (Iran, the Saudis, Gulf states, Lebanon, Turkey) to stop support for those who reject the peace agreement. As security grows, there will be a phased withdrawal of the IDF and the gradual assumption of responsibility for security by Palestinian police.

The Palestinian state has to become economically viable; a gradual process. The two states have been partially integrated for decades and will become even more so with peace. The Rand Corporation and other thinktanks and international agencies have given this some thought and come up with some numerical estimations. Solar energy development and water management are obvious targets for joint projects with Israel. With growing security, Palestine labor migration to Israel will increase. The export of Gazan agricultural products (e.g. strawberries and vegetables) and textiles can be reestablished as before 2005; investment in manufacturing for export to Arab states will become attractive. As economic cooperation grows, agreements and practices will be worked out regarding the flow of goods and people, transportation, currency, official languages, religious rights, law courts, education, licenses and degrees, tariffs, identity papers, and coordinated governance, in particular for Jerusalem.

Further side agreements will be made about timetables and conditions for phasing out the occupation and phasing in Palestinian governance.

The Permanent peace settlement between Israel and the new Palestinian state will be approved by all stakeholders in an international peace treaty and legitimized through referenda by the Israeli and Palestinian populations.

\section{CONCLUSION}

These are guiding, preliminary ideas that are meant to start a discussion. The Israeli and Palestinian publics will have to be convinced that a peace agreement is 
preferable to the status quo and to alternatives. Scholars can't make that happen; leaders, public intellectuals, the media and international stakeholders can. It worked in South Africa when the leaders of the African and white populations came to share the view that a viable South Africa needed compromises and cooperation by both groups; it worked in Europe when German and French leaders understood that European reconstruction and future peace necessitated Franco-German cooperation. In time, it may also happen for Israelis and Palestinians. 